УДК 621.1:532.59:532.66

О. Ю. Розіна, В. Б. Роганков

Одеська національна академія харчових технологій, вул. Канатна, 112, Одеса, 65039, Україна

\title{
ВИЗНАЧЕННЯ ОПТИМАЛЬНИХ УМОВ ФОРМУВАННЯ ПОТОКУ ТЕПЛА В АКУСТИЧНО- МУ ПОЛІ НА ПЕРЕРІЗІ КАПІЛЯРА
}

3 використанням спеціально розробленого програмного забезпечення проведено чисельне дослідження впливу параметрів ультразвукової кавітації на потік тепла, спрямованого через переріз капіляра, зануреного в рідину, якщо кавітаџія збуджена під каналом капіляра. Проведений аналіз впливу частоти ультразвукових коливань, рівноважної температури рідини, діаметру капіляра на потужність сформованого теплового потоку. Знайдені обмеження, які накладає частота ультразвукових коливань на діапазон максимальних радіусів кавітаційних порожнин та припустимий діаметр капілярів. Визначені оптимальні значення параметрів, при яких потужність теплового потоку є максимальною.

Ключові слова:Перенос тепла-Капіляр - Ультразвукова кавітація - Фазове перетворення парарідина.

Е. Ю. Розина, В. Б. Роганков

Одесская национальная академия пищевых технологий, ул. Канатная, 112, Одесса, 65039, Украина

\section{ОПРЕДЕЛЕНИЕ ОПТИМАЛЬНІХ УСЛОВИЙ ФОРМИРОВАНИЯ ПОТОКА ТЕПЛА В АКУСТИЧЕСКОМ ПОЛЕ НА СРЕЗЕ КАПИЛЛЯРА}

С использованием спечиально разработанного программного обеспечения проведено численное исследование влияния параметров ультразвуковой кавитащии на поток тепла, направленный в канал капилляра, погруженного в жидкость, если кавитация возбуждена под каналом капилляра. Проанализировано влияние частоты ультразвуковых колебаний, равновесной температуры жидкости на мощзность сформированного теплового потока. Определены ограничения, накладываемые частотой ультразвуковых колебаний на диапазон максимальных радиусов кавитационных полостей и допустимый диаметр используемых капилляров. Определены оптимальные значения параметров, при которых мощчнсть теплового потока достигает максимального значения.

Ключевые слова: Перенос тепла - Капилляр - Ультразвуковая кавитация - Фазовый переход газ-жидкость

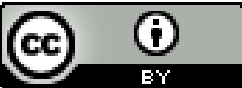

This work is licensed under the Creative Commons Attribution International License (CC BY). http://creativecommons.org/licenses/by/4.0/

\section{I. ВСТУП}

Паралельно $з$ підвищенням ефективності та екологічної безпеки традиційних систем охолодження, що використовують теплоту фазового перетворення рідина-пара, активно досліджуються та удосконалюються нетрадиційні системи охолодження. Серед них слід зазначити системи, які використовують феромагнетики $з$ точкою Кюрі, близькою до кімнатної температури $20^{\circ} \mathrm{C}$ [1]. Відносно новими охолоджувачами $€$ акустичні холодильні пристрої на базі зворотного термоакустичного ефекту [2]. Виходячи 3 того, що ультразвукова кавітація $є$ фізичним «поєднанням» акустичних коливань значної амплітуди і локальних фазових перетворень типа рідинапара, у роботі [3] нами розроблена концептуальна модель формування потоку тепла через переріз капіляра, зануреного у рідину, якщо під каналом капіляра збуджений кавітаційний процес.

За допомогою спеціально розробленої програми отримана можливість динамічного моделю- вання, що дозволяє проводити чисельні оптимізуючи експерименти, змінюючи акустичні і термодинамічні параметри системи у широкому діапазоні. Зокрема, мова іде про керівний параметр - частоту ультразвукових коливань, яка визначає динаміку кавітаційного процесу. Крім того, у широкому діапазоні можливо задавати параметри рідини, що відносяться до фазового переходу, зокрема його рівноважну температуру та зв'язані з нею локальні тиск та густину насиченої пари. На цьому етапі є можливим в принципі швидко отримати велику кількість результатів, з метою їх подальшого фронтального порівняння та аналізу. Але необгрунтоване зростання масиву даних, як правило, значно ускладнює їх упорядкування та узагальнення. Отже, на цьому етапі стає актуальною задача планування чисельного експерименту, тобто вибору а) оптимального діапазону зміни незалежних параметрів (температури рідини, частоти ультразвуку, максимального радіусу порожнини); а також б) оптимальної кількості проведених розрахунків в обраному діапазоні. Метою даної роботи є визначення 
фізично обгрунтованих обмежень для параметрів, що обумовлюють ефективний тепловідвід і суттєве охолодження внаслідок збудження кавітації під нижнім перерізом капіляра.

\section{II. ФОРМУВАННЯ ПОТОКУ ТЕПЛА І ПАРА- МЕТРИ, ЩО ЙОГО ВИЗНАЧАЮТЬ}

Відповідно до запропонованої в нашій попередній роботі [3] моделі формування теплового потоку через переріз капіляра базовими є два положення. По-перше, кавітаційний процес, розглядається як періодична послідовність локальних фазових перетворень рідина-пара. Процес механічного розтягнення порожнини супроводжується випаруванням в неї певної кількості рідини, що потребує відповідної теплоти

$$
\Delta q_{(-)}=r\left(T_{o}\right) \cdot \Delta m .
$$

У цьому виразі індекс (-)означає, що тепло відібрано від тонкого поверхневого шару рідини, що обмежує порожнину, $r$ - ефективна (вимірювальна) питома теплота пароутворення, яка у загальному випадку залежить від типу рідини і температури навколишнього середовища $T_{o}, \Delta m$ - маса рідини, що перетворилась на пару протягом півперіоду розтягнення порожнини від початкового радіуса $R_{o}$ до максимального радіуса $R_{\max }$, досягнутого на кінцевій стадії розширення. Відповідно зворотний процес, змикання кавітаційної порожнини супроводжується конденсацією пари на іiї поверхні, та виділенням теплоти $q_{(+)}$. В загальному випадку процеси розширення і випарування та наступне змикання і конденсація не $\epsilon$ повністю оборотними. Але якщо ідеалізоване випарування відбувається у вакуумну порожнину, і швидкість змикання достатня для повного змикання порожнини протягом півперіоду стиснення, виконується приблизна рівність $\Delta q_{(+)} \approx \Delta q_{(-)} \approx Q .3$ цього припущення випливає наступне. Якщо порожнини пульсують відносно нерухомого центру, або хаотично рухаються в об'ємі акустичного поля, відбувається періодична (з частотою ультразвукових коливань $v$ ) незначна зміна температури приповерхневого шару рідини, але формування потоку теплоти відбуватися не буде.

Картина повинна принципово змінитися, якщо кавітаційний процес буде локалізований під нижнім перерізом капіляра. Внаслідок викривлення акустичного поля на вході в капіляр і експоненціального загасання амплітуди звукового тиску в каналі капіляра відбувається експериментально зареєстрований нами спрямований рух кавітаційних порожнин до каналу капіляра. Очевидно, що це зумовлює розділення у просторі процесів, які ідуть 3 поглинанням або виділенням тепла: теплота $q_{(-)}$відбирається в об'ємі під капіляром, а теплота $q_{(+)}$віддається рідині вже в каналі капіляра на висоті порядку його діаметpa.

Враховуючи, що переріз капіляра перетинає $N$ кавітаційних порожнин за час порядку $4 \cdot(1 / v)$ (результат експерименту, представлений у попередній роботі [3]), вираз для густини потоку тепла, що перетинає переріз капіляра площею $A_{\perp}$ внаслідок перемі- щення $N$ кавітаційних порожнин протягом часу $\Delta t$, має вигляд

$$
\begin{gathered}
j_{q}=\frac{Q}{\Delta t \cdot A_{\perp}} \cdot N=\frac{r\left(T_{o}\right) \cdot \Delta m}{A_{\perp}} \cdot \frac{v}{4} N= \\
=\frac{r\left(T_{o}\right) \cdot \Delta m}{\pi \cdot d_{\text {кan }}^{2}} \cdot v \cdot N .
\end{gathered}
$$

У цьому виразі $q$ - теплота, відібрана від рідини внаслідок іiі випарування у зростаючу порожнину, $r-$ локальна ефективна питома теплота пароутворення рідини, $v$ - частота ультразвукових коливань, $d_{\text {каn }}-$ діаметр капіляра, зануреного у рідину. Враховуючи, що маса пари $\Delta m \in$ добутком густини пари $\rho\left(T_{o}\right)$ та об'єму порожнини $(4 / 3) \cdot \pi \cdot\left(R_{\max }\right)^{3}$, виразу (2) можна надати вигляду

$$
j_{q} \approx \frac{4 \cdot r\left(T_{o}\right) \cdot \rho\left(T_{o}\right) \cdot R_{\max }^{3}}{3 \cdot d_{\text {каn }}^{2}} \cdot v \cdot N .
$$

Як видно з виразу (3), є три параметри, які можна варіювати в експерименті. Це частота ультразвукових коливань $v$, діаметр капіляра $d_{\text {кап }}$ та рівноважна температура рідини $T_{o}$. Проаналізуємо, чи є ці параметри реально незалежними, та які обмеження їх зміна накладає на максимальний радіус порожнини $R_{\text {max. }}$.

\section{II.А. Обмеження, що накладає частота ультразву- кових коливань}

Нижня границя діапазону зміни частот визначається виключно технологічними можливостями. У промисловості нижньою границею частоти при використанні ультразвуку в рідині є значення порядку 15 кГц [4] (це значення визначається порогом чутливості вуха людини (5 ..7 кГц). Отже зниження частот обмежено санітарними нормами. Серед низькочастотних ультразвукових випромінювачів найбільш поширеними $є$ такі, що мають резонансну частоту порядку 20 кГц. Але, як видно з виразу (3), питання полягає у тому, до якої межі можна збільшувати частоту. Зазначимо, що при технологічному використанні ультразвуку в рідині верхнею межею частот $\epsilon$ 100 кГц, тому що з підвищенням частоти збудження кавітації в рідині значно ускладнюється.

У рамках загальної акустики розрізняють поняття «тонкі акустичні трубки» та «акустичні капілярні канали» $[5,6]$. Перше поняття відноситься до циліндричних труб, діаметр яких $d_{m p}$ одного порядку 3 довжиною ультразвукової хвилі $\lambda$. Якщо діаметр обраної труби задовольняє приблизному співвідношенню

$$
d_{m p} \approx 0,61 \lambda,
$$

в їі канал вільно входить акустична (ультразвукова) хвиля. Якщо таку трубку примусово заповнювати рідиною, при встановлені рідини на певному рівні відбувається резонансне підсилення акустичного поля в трубі [5]. У таких умовах відбувається збудження кавітації в пучностях звукового тиску в каналі трубі на значній відстані від iї перерізу, тобто формування потоку тепла у відповідності до запропонованої моделі є неможливим. Звернемо увагу, що акустичне поняття «капіляр» відрізняється від моле- 
кулярно-обгрунтованого поняття капіляр. Наприклад, на частоті 500 кГц у воді трубка з внутрішнім діаметром 2 мм $є$ тонкою резонансною трубкою, але 3 молекулярної точки зору це капіляр із звичайними капілярними властивостями.

Поняття акустичних капілярів передбачає виконання сильної нерівності

$$
\lambda>d_{\text {каn }} .
$$

За такої умови на вході в капіляр внаслідок дифракції відбувається експоненціальне загасання ультразвукової хвилі. Отже на вході в капіляр формується наднеоднорідне акустичне поле [6]. Саме ця неоднорідність є причиною локалізації кавітаційного середовища під каналом капіляра, а також періодичного зміщення кавітаційних порожнин до каналу [7]. Оскільки базовими положенням моделі формування теплового потоку через переріз капіляра є саме локалізація кавітаційного процесу і періодичне зміщення порожнин до каналу капіляра, співвідношення (5) має обов'язково виконуватися. Це означає, що діаметр капіляра має бути приблизно на два порядки менше, ніж довжина хвилі. Отже, нерівність (5) можна переписати у вигляді обмеження

$$
D_{\text {кап }} \leq \lambda \cdot 10^{-2}
$$

Іншими словами, для даної довжини хвилі допустимим $\epsilon$ тільки такий набір капілярів, у якого максимальний капіляр має внутрішній діаметр $D_{\text {кап }}$, що задовольняє нерівності (6).

В Таблиці 1 представлені довжини хвиль $\lambda$, що формуються в ультразвуковій ванні при збуджені коливань відповідної частоти $v$, розраховані за формулою $\lambda=c / v$ ( $c$ - швидкість звуку у даному середовищі, і для води дорівнює 1490 м/с при $20^{\circ} \mathrm{C}$ ([4,c.327]). В таблиці представлений максимальний допустимий діаметр капіляра $D_{\text {кап }}$, що задовольняє обмеженню (6), розрахований для кожної частоти.

Таблиця 1 - Параметри ультразвукового поля та від повідні максимально допустимі значення діаметр капіляра $D_{\text {кап }}$ та радіуса кавітаційної порожнини $R_{\text {max }}^{*}$

\begin{tabular}{|c|c|c|c|}
\hline$v, \mathrm{\kappa} Ц ц$ & $\lambda \cdot 10^{2}, \mathrm{M}$ & $D_{\text {каn }} \cdot 10^{3}, \mathrm{M}$ & $R^{*}{ }_{\max } \cdot 10^{4}, \mathrm{M}$ \\
\hline 20 & 7,45 & 0,745 & 1,242 \\
\hline 55 & 2,71 & 0,271 & 0,452 \\
\hline 100 & 1,49 & 0,149 & 0,248 \\
\hline
\end{tabular}

3 даних таблиці випливає, що зростання частоти веде до зменшення параметру $D_{\text {каn }}$, i, на перший погляд, це позитивний фактор для формування потоку тепла, адже у виразі (3) діаметр знаходиться у знаменнику, і слід очікувати зростання густини потоку тепла для тонких капілярів. Але необхідно звернути увагу на таке обмеження. Щоб сформувався тепловий потік, кавітаційні порожнини мають без перешкод у достатній кількості увійти до каналу капіляра. Для кожного одиночного газового пухирця, що рухається в каналі капіляра, це має місце, якщо від стінки каналу до поверхні пухирця буде відстань порядку діаметра пухирця [8]. Для кавітаційних порожнин також відомо, що положення твердої стінки не впливає на змикання порожнин, якщо відстань від центру порожнини перевищує діаметр капіляра [9].
Обидві умови не протирічать одна одній, отже маємо ще одне обмеження: для радіусу порожнини, що перетинає переріз капіляру, має виконуватися нерівність $R^{*}{ }_{\max } \leq(1 / 6) \cdot D_{\text {кап }}$. Оптимальні граничні значення для радіусу порожнини $R_{\text {max }}^{*}$ на даній частоті також представлені у таблиці 1 .

\section{II.B. Випаровування при розтягненні одиночної порожнини}

Величина $R_{\max }$ в явному вигляді присутня у виразі (3) і має ключове значення для розрахунку потоку тепла, тому що визначає масу пари $\Delta m$, що випаровується з поверхні порожнини при їі розтягненні. В роботі [3] нами розроблений алгоритм визначення $\Delta m$. Алгоритм передбачає заміну процесу безперервного зростання радіусу від $R_{\min }$ до $R_{\max }$ на модельну послідовність дискретних кроків, в кожному 3 яких протягом часу $\Delta t_{i}$ радіус збільшується на величину $\Delta r=r_{i}-r_{i-1}==0,1 \cdot R_{\max }$. На кожному кроці формується вакуумний прошарок, у який випаровується кількість рідини $\Delta m_{i}$. Величина $r_{i}$ відповідає радіусу порожнини у даний момент часу, і на цій поверхні пара $є$ насиченою $\rho_{\text {нас }}$. На поверхні з радіусом $r_{i-1}$ встановлюється значення густини $\rho_{i-1}$ яке $є$ результатом попередніх $(i-1)$ процесів. Процес випарування у сформований тонкий шар розглядається як процес дифузії, і описується рівнянням Фіка

$$
\Delta m_{i}=D \cdot \frac{\rho_{\mu a c}-\rho_{i-1}}{\Delta r_{i}} \cdot\left(4 \cdot \pi \cdot r_{i}^{2}\right) \cdot \Delta t_{i}
$$

У цьому виразі $D$ - коефіцієнт дифузії молекул рідини, що випаровується; інтервал часу $\Delta t_{i}$ визначається частотою, а саме $\Delta t_{i}=1 /(20 \cdot v)$.

Звернемо увагу, що вираз (7) передбачає що на кожному кроці розширення пара в порожнині $є$ ненасиченою. Тестування програми показало, що на низьких частотах таке припущення несправедливе. При заданих умовах можна визначити час $\tau_{\text {нас }}$, необхідний для випарування кількості рідини у створений $i$-тий вакуумний прошарок, достатньої для досягнення стану насиченої пари. На низьких частотах параметр $\Delta t_{i}$ значно перевищує час насичення $\tau_{\text {нас. }}$ Отже, за такої умови пара в порожнині є насиченою протягом всього півперіоду розширення порожнини, тому $\Delta m_{i}$ визначається формулою

$$
\Delta m_{i}=\rho_{\text {нас }} \cdot 4 \cdot \pi\left(r_{i}^{2}-r_{i-1}^{2}\right) \cdot 0,1 \cdot R_{\max } .
$$

Відповідно, реалізовані такі варіанти розрахунків. А) протягом усього півперіоду зростання порожнини $\Delta t_{i}>\tau_{\text {нас }}$, тобто пара у кожному створеному прошарку стає насиченою; $\Delta m_{\mathrm{i}}$ визначає вираз (8). Б) на кожному і-тому кроці справедлива нерівність $\Delta t_{i}<$ $\tau_{\text {нас }}$ і пара залишається ненасиченою протягом всього півперіоду; величину $\Delta m_{\mathrm{i}}$ визначає вираз (7). В) ускладнений варіант розрахунку, коли від початку до деякого кроку розширення пара $є$ насиченою, $\Delta m_{\mathrm{i}}$ визначає вираз (8), на певному кроці розширення співвідношення між інтервалами $\Delta t_{i}$ i $\tau_{\text {нас }}$ змінюється на протилежне, і величину $\Delta m_{\mathrm{i}}$ визначає вираз (7).

Зрозуміло, що для формування потужного потоку 
тепла оптимальним є режим «повільного» розтягнення порожнини на низьких частотах, коли протягом всього процесу розширення встановлюється насичення і випаровується максимально можлива кількість рідини при даній температурі.

На рисунку 1 представлені результати розрахунків $\Delta q_{i}=r\left(T_{o}\right) \cdot \Delta m_{i}$ для умов, коли швидкість випарування достатня для того, щоб протягом розширення порожнини пара в ній досягала стану насиченості, тобто величина $\Delta m_{i}$ для всіх кроків розширення визначалась 3 використанням виразу (8). На горизонтальній осі відкладений формальний параметр $i-$ номер кроку розрахунку. Відмітимо, що він однозначно характеризує важливий фізичний параметр для даної задачі - у відносних одиницях це поточний радіус порожнини, який визначається як $r_{i}=\left(0,1 \cdot R_{\max }\right) \cdot i$.

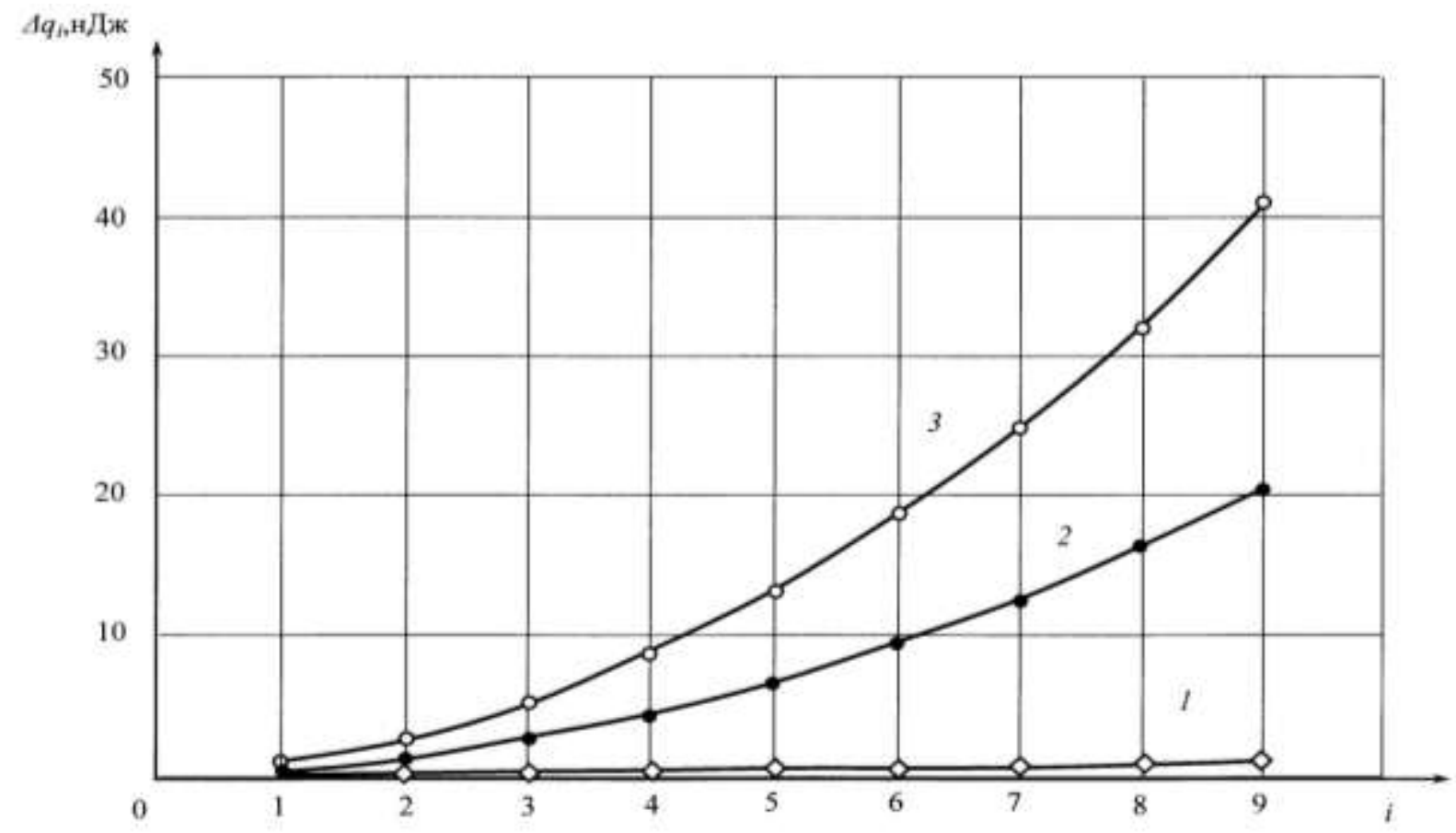

Рисунок 1 - Залежність кількості теплоти $\Delta q_{i}$, виділеної в рідині при покроковому зростанні радіусу порожнини, від номеру кроку розрахунку. Графіки отримані для таких умов: середня температура рідини $291 \mathrm{~K}$ $\left(18^{\circ} \mathrm{C}\right)$; максимальні радіуси порожнин дорівнюють для кривої 1 - 0,03 мм; 2- 0,08 мм; 3 - 0,1 мм.

Показані залежності мають очікуваний характер. Зростання поточного радіусу порожнини $r_{i}$ веде до відповідного зростання об'єму прошарку, який заповнюється насиченою парою, і відповідним зростанням величини кількості теплоти $\Delta q_{i}$, за законом близьким до кубічної параболи. Також є очікуваним, що зростання максимального радіусу порожнини веде до зростання кількості відібраного тепла відповідно до закону $\Delta q_{i} \sim\left(R_{\max }\right)^{3}$, тобто криві $\Delta q_{i}\left(r_{i}\right)$, що відповідають більшим значенням $R_{\max }$, розташовані в області більших значень $\Delta q_{i}$.

Для варіанту Б) покрокового розрахунку кількості теплоти $\Delta q_{i}$, відведеної від рідини на $i$-тому кроці розширення порожнини, результати представлені у Таблиці 2. У таблиці також показана густина пари $\rho_{i}$, що локально встановлюється в порожнині. Результати представлені для частоти коливань 100 кГц, і двох температур при відповідному наборі максимальних радіусів порожнин. Для порівняння в таблиці також представлені значення густини наси-

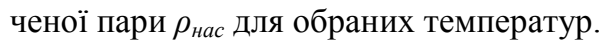

Проаналізуємо основні результати. Для температури $358 \mathrm{~K}\left(85^{\circ} \mathrm{C}\right)$ таблична густина насиченої пари становить $354,6 \cdot 10^{-3}$ кг/ ${ }^{3}$. Для всіх порожнин вказаного радіусу вже на першому кроці при зростанні радіусу від $r_{l}=0,1 \cdot R_{\max }$ до $r_{2}=0,2 \cdot R_{\max }$ густина пари в порожнині значно менша за величину $\rho_{\text {нас }}$, i далі в процесі росту порожнини густина пари в неї суттєво зменшується. На кінцевій фазі росту (від $r_{6}=0,6 \cdot R_{\max }$ до $r_{10}=R_{\max }$ ) густина пари виходить на стаціонарне локальне значення, яке більше ніж у 5 разів відрізняється від величини $\rho_{\text {нас }}$ (для порожнин радіусу 0,1 мм). Аналогічну ситуацію маємо і для температури $343 \mathrm{~K}\left(70^{\circ} \mathrm{C}\right)$ : таблична густина насиченої пари за таких умов становить $196,6 \cdot 10^{-}$ ${ }^{3}$ кг/м ${ }^{3}$, а встановлене значення локальної густини пари в порожнині виходить після 4-6 кроків розширення на стаціонарне значення, яке для порожнини радіусом 0,125 мм дорівнює $40 \cdot 10^{-3} \mathrm{\kappa г} / \mathrm{m}^{3}$. Це також приблизно у 5 разів менше ніж вказане табличне значення $\rho_{\text {нас }}=196 \cdot 10^{-3}$, кг/ $\mathrm{M}^{3}$ для даної температури.

Підкреслимо, що зменшення локальної густини пари в декілька раз у порівнянні з табличним значенням, яке спостерігається у варіанті Б) $є$ досить суттєвим. Це безумовно свідчить про значну неефективність тепловідводу за умови створення високочастотних ультразвукових коливань. 
Таблиця 2. Результат покрокового визначення кількості теплоти $\Delta q_{i}$, відібраної від рідини, та густини пари, що встановилась у порожнині на $i$-тому кроці розширення ( $v=100$ кГц)

\begin{tabular}{|c|c|c|c|c|c|c|c|c|c|c|c|}
\hline & $\begin{array}{l}R_{\max } \\
\text { мM }\end{array}$ & & 1 & 2 & 3 & 4 & 5 & 6 & 7 & 8 & 9 \\
\hline \multirow{6}{*}{ 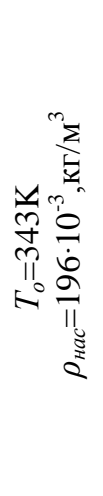 } & \multirow{2}{*}{0,125} & $\Delta q_{i} \cdot 10^{9}$,Дж & \begin{tabular}{c|}
6,2 \\
2
\end{tabular} & 12,28 & 27,62 & 45,95 & 68,70 & 95,88 & 127,6 & 163,8 & 204,5 \\
\hline & & $\rho_{i} \cdot 10^{3}, \mathrm{\kappa} \Gamma / \mathrm{M}^{3}$ & $\begin{array}{l}65, \\
86 \\
\end{array}$ & 43,69 & 41,37 & 40,73 & 40,47 & 40,34 & 40,27 & 40,22 & 40,19 \\
\hline & \multirow{2}{*}{0,100} & $\Delta q_{i} \cdot 10^{9}$,Дж & $\begin{array}{l}4,9 \\
72\end{array}$ & 8,079 & 20,11 & 33,12 & 49,36 & 68,84 & 91,56 & 117,5 & 146,8 \\
\hline & & $\rho_{i} \cdot 10^{3}, \mathrm{\kappa} \Gamma / \mathrm{M}^{3}$ & $\begin{array}{l}89, \\
08\end{array}$ & 57,45 & 56,85 & 56,61 & 56,48 & 56,40 & 56,35 & 56,31 & 56,29 \\
\hline & \multirow{2}{*}{0,075} & $\Delta q_{i} \cdot 10^{9}$,Дж & $\begin{array}{l}3,7 \\
18 \\
\end{array}$ & 3,222 & 13,60 & 20,26 & 30,18 & 42,10 & 56,03 & 71,89 & 89,77 \\
\hline & & $\rho_{i} \cdot 10^{3}, \mathrm{~K} \Gamma / \mathrm{M}^{3}$ & $\begin{array}{c}13 \\
8,8\end{array}$ & 70,49 & 82,03 & 81,87 & 81,76 & 81,68 & 81,63 & 81,60 & 81,57 \\
\hline \multirow{6}{*}{ 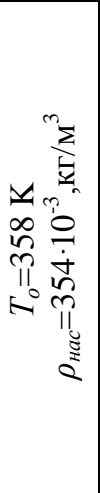 } & \multirow{2}{*}{0,100} & $\Delta q_{i} \cdot 10^{9}$,Дж & $\begin{array}{l}5,1 \\
14 \\
\end{array}$ & 10,45 & 23,20 & 38,67 & 57,78 & 80,66 & 107,3 & 137,8 & 172,1 \\
\hline & & $\rho_{i} \cdot 10^{3}, \mathrm{\kappa} \Gamma / \mathrm{M}^{3}$ & $\begin{array}{l}11 \\
0,6 \\
\end{array}$ & 72,94 & 68,40 & 67,13 & 66,61 & 66,36 & 66,21 & 66,12 & 66,06 \\
\hline & \multirow{2}{*}{0,075} & $\Delta q_{i} \cdot 10^{9}$,Дж & $\begin{array}{l}5,0 \\
84 \\
\end{array}$ & 9.780 & 22,24 & 37,01 & 55,27 & 77,13 & 102,6 & 131,7 & 164,5 \\
\hline & & $\rho_{i} \cdot 10^{3}, \mathrm{\kappa} \Gamma / \mathrm{M}^{3}$ & $\begin{array}{l}16 \\
2,2\end{array}$ & 104,3 & 103,4 & 103,0 & 102,8 & 102,7 & 102,6 & 102,5 & 102,5 \\
\hline & \multirow[t]{2}{*}{0,05} & $\Delta q_{i} \cdot 10^{9}$,Дж & $\begin{array}{l}2,5 \\
57\end{array}$ & 0,951 & 9,617 & 12,06 & 18,52 & 25,87 & 34,43 & 44,20 & 55,20 \\
\hline & & $\rho_{i} \cdot 10^{3}, \mathrm{\kappa} \Gamma / \mathrm{M}^{3}$ & $\begin{array}{l}30 \\
9,7\end{array}$ & 121,0 & 175,8 & 170,2 & 169,7 & 169,5 & 169,4 & 169,3 & 169,3 \\
\hline
\end{tabular}

Повертаючись до Рисунку1, зазначимо, що нетривіальні висновки можуть бути зроблені, якщо його розглянути у відповідності до Таблиці 1. Дійсно, крива 1 побудована для порожнини з радіусом $R_{\max }=0,03$ мм, який перевищує оптимальний радіус порожнини для частоти 100 кГц. Тобто набір допустимих кривих $\Delta q_{i}\left(r_{i}\right)$, для частот порядку 100 кГц мають бути нижчими, ніж положення кривої 1. Крива 2 була побудована для порожнини 3 максимальним радіусом $R_{\max }=0,08$ мм, який також перевищує оптимальний радіус порожнини для частоти 55 кГц. Відповідно, під кривою 2 лежить весь набір допустимих значень залежності $\Delta q_{i}\left(r_{i}\right)$ для частот порядку 55 кГц. Крива 3 отримана для порожнини 3 максимальним радіусом $R_{\max }=0.1 \mathrm{мм}$, і це значення дещо менше, ніж оптимальний радіус порожнини для частоти 20 кГц. Очевидно, що саме на цій частоті маємо найбільший діапазон припустимих радіусів порожнин, і відповідно, найбільшу величину визначального теплового параметру $\Delta q_{i}$ на кожному етапі розширення порожнини.

Підведемо підсумок цього обговорення. Параметр $\Delta q_{i}$, а відповідно, і сумарна кількість теплоти $Q=\Sigma \Delta q_{i}$ формально не повинні залежати від частоти ультразвукових коливань. Але встановлений в роботі вплив частоти є досить суттєвим. Для кожної частоти спостерігається діапазон радіусів $R_{\max }$, у якому можливо організувати звукокапілярний перенос тепла. Iз зростанням частоти цей діапазон значно звужується і обмежується малими радіусами. Таким чином, Рисунок 1 та результати, представлені у Таблиці 2, де- монструють недоцільність у будь-якій ситуації підвищення частоти ультразвукових коливань, незважаючи на передбачувану виразом (1) лінійну залежність густини теплового потоку $j_{q}$ від частоти коливань. Зазначимо також, що представлена на Рисунку 1 залежність кількості теплоти $\Delta q_{i}$, яка відбирається від рідини на стадії розширення, приблизно співпадає з графіком кількості теплоти, яка віддається рідині на етапі стиснення порожнини. Тобто для умов, коли пара в порожнині $є$ насиченою протягом усього періоду ультразвукової хвилі ці два процеси є взаємо-оборотні 3 точки зору термодинамічної теорії фазових рівноважних переходів.

\section{II.В. Вплив рівноважної температури на випару- вання при розтягненні одиночної порожнини}

Як видно з виразу (1), густина потоку тепла залежить від кількості рідини, що випаровується у порожнину, а цей параметр у рамках розробленої моделі визначається значною мірою густиною насиченої пари. Тому на перший погляд обмеження по збільшенню частоти можна деякою мірою «компенсувати» зростанням температури і ії наближенням до температури кипіння даного теплоносія. Однак необхідно визначити, до якої межі підвищення температури рідини є доцільним.

На рис.2 представлені залежності кількості теплоти, відібраної від рідини внаслідок ії випарування, при покроковому зростанні радіусу порожнини від $R_{o}=0,1 \cdot R_{\max }$ до $R_{\max }, \quad\left(\Delta R=0,1 R_{\max }\right)$. Приведений набір кривих відповідає порожнині з максимальним 
радіусом 0,1 мм, та охоплює діапазон температур від 15 до $55^{\circ} \mathrm{C}$. Це відповідає умовам, коли протягом розширення порожнини на даному поточному кроці пара в порожнині встигає дістати стану насиченості, тобто реалізується варіант розрахунку А). Як видно 3 графіків, підвищення температури від $15^{\circ} \mathrm{C}$ до $55^{\circ} \mathrm{C}$ веде до суттєвого зростання кількості теплоти $\Delta q_{i}$ на кожному кроці розширення. Це обумовлено швидким зростанням густини $\rho_{\text {нас }}$ у вказаному діапазоні температур.

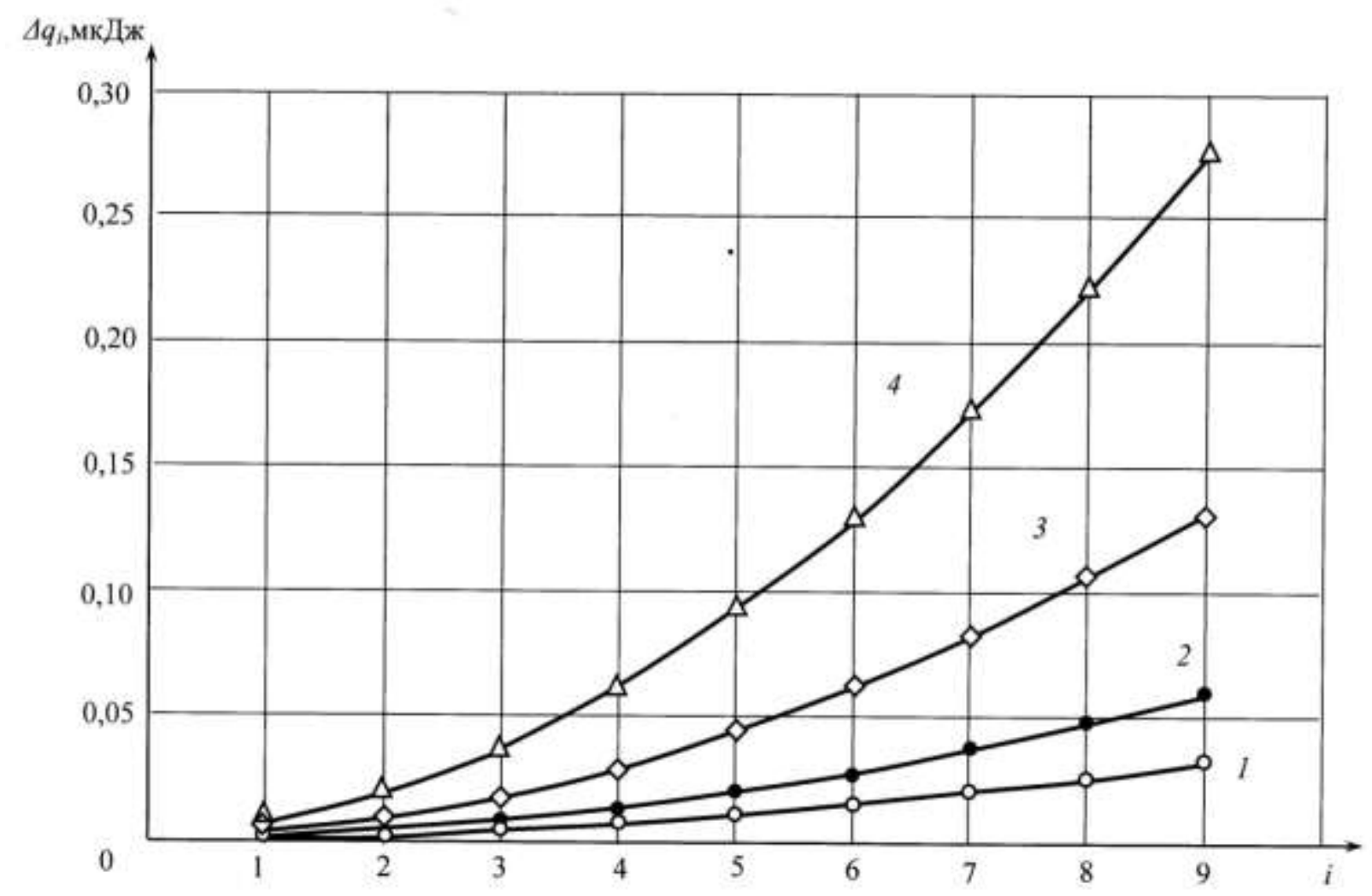

Рисунок 2 - Залежність кількості теплоти, відібраної від рідині при покроковому зростанні радіусу порожнини $r_{i}=\left(0,1 \cdot R_{\max }\right) \cdot i$ від номеру кроку розрахунку $i$.

Графіки отримані для таких умов: максимальний радіус порожнин становить 0,1 мм; частота коливань

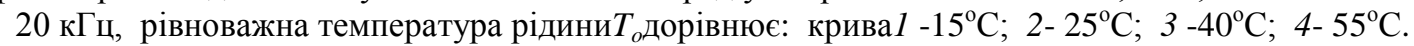

Отже, термодинаміка не накладає обмежень на рівноважну температуру рідкого теплоносія при достатньо низьких частотах.

Але такі обмеження виявляються, якщо мова іде про стабільність кавітаційного процесу, збудженого під нижнім зрізом капіляра. Відомо, що стабільність кавітації під каналом капіляра в експерименті визначається середньою концентрацією зародків кавітації в рідині. Експериментальні дослідження для дистильованої води показали, що попередня дегазація кип'ятінням та охолодженням до температури $20^{\circ} \mathrm{C}$ без доступу повітря суттєво підвищує кавітаційну стабільність рідини. У воді, підготовленій таким чином, кавітація може бути стимульована виключно під каналом капіляра, і після збудження існує у такому стані практично необмежений час [10]. Підвищення температури води веде до зростання кількості розчиненого у ній газу (повітря), відповідно знижується кавітаційна стійкість рідини. Отже, у досліджуваному процесі проявляють себе два незалежних фактори, що суттєво погіршують умови для формування стабільного теплового потоку через переріз капіляра. По-перше, внаслідок загального зниження кавітаційної стійкості води, кавітаційний процес випадково виникає по всьому об'єму рідини, і збудження кавітації під каналом капіляра стає недосяжним. По-друге, якщо кавітація стимульована під каналом капіляра в умовах значної кількості розчиненого газу, загальний діаметр кавітаційної хмари може на порядок перевищувати діаметр каналу капіляра. В такому випадку флуктуаційна зміна амплітуди звукового поля або акустичного навантаження на випромінювач, а також випадкові порушення симетрії хмари відносно осі капіляру можуть привести до зриву процесу кавітації, i, як наслідок, процес переносу теплоти через переріз капіляра буде перериватися. Залежності $\Delta q_{i}\left(r_{i}\right)$, представлені на рисунку 2 для діапазону температур з верхнею границею $55^{\circ} \mathrm{C}$, у якому кавітаційний процес ще залишається стабільним під каналом капіляра. Можливість розширення цього діапазону для конкретних теплоносіїв і наближення рівноважної температури рідини до температури кипіння має вирішуватися в кожному випадку або експериментально, або із застосуванням адекватної моделі локальних фазових перетворень. 


\section{III. УЗАГАЛЬНЕННЯ РЕЗУЛЬТАТІВ}

Для визначення густини потоку тепла $j_{q}$, відібраного 3 охолоджуваної області під нижнім перерізом капіляра внаслідок збудження кавітаційного процесу, необхідно оцінити сумарний ефект $Q=\Sigma \Delta q_{i}$, що вно- сить кожна порожнина в процесі іï росту. Результати розрахунків кількості теплоти $Q$, проведених для порожнин з різними максимальними радіусами при різних рівноважних температурах рідини узагальнені і графічно представлені на Рисунку 3.

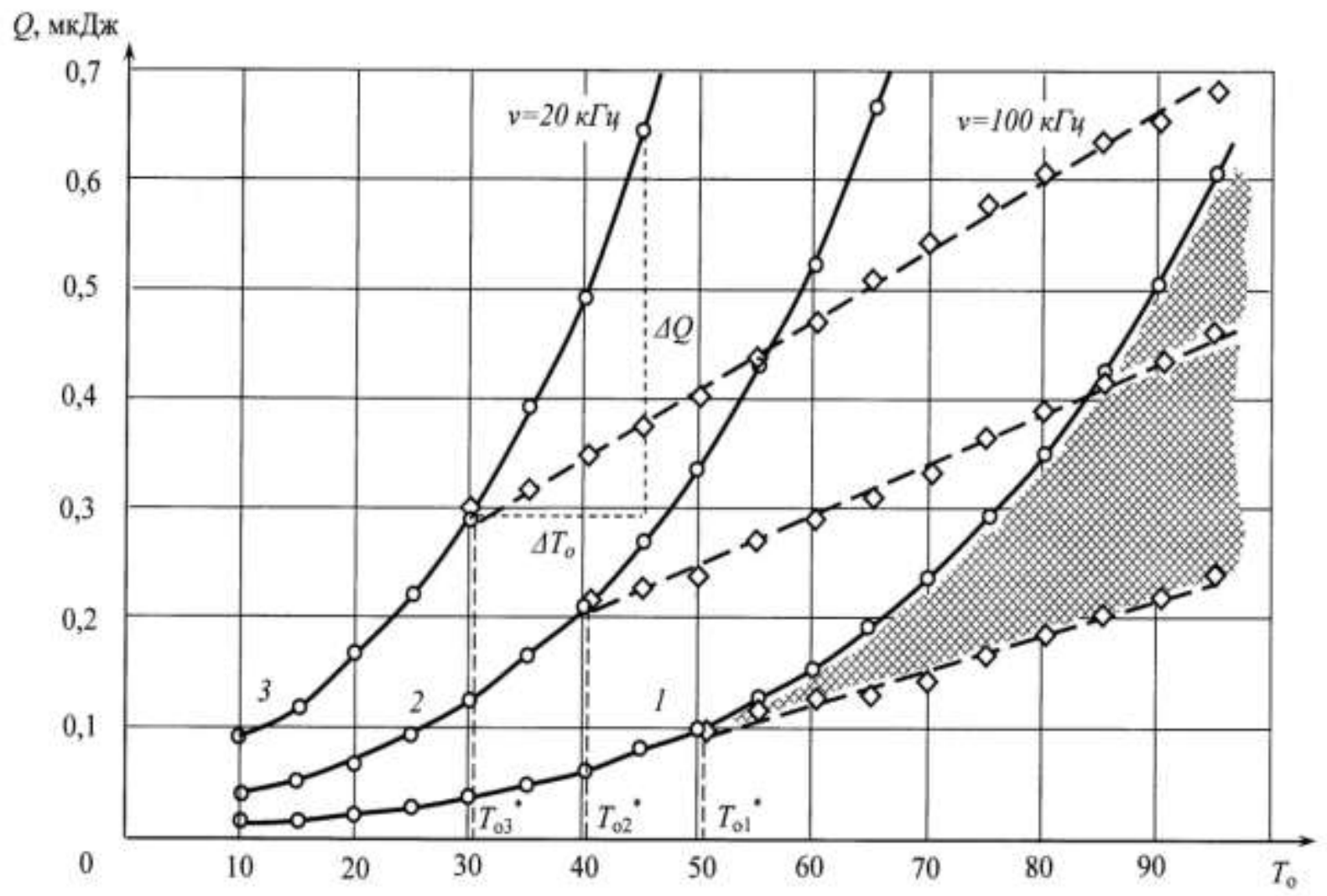

Рисунок 3 - Вплив температури середовища на кількість теплоти $Q$, необхідної для випарування рідини в процесі розширення порожнини.

Максимальний радіус порожнин становить: крива 1 - 0,050 мм, 2 - 0,075 мм,3 - 0,10 мм

Для всіх представлених радіусів порожнин зростання рівноважної температури середовища $T_{o}$ веде до зростання параметру $Q$. Але, як видно, для кожного радіусу існує гранична температура $T_{0}{ }^{*}$, при якій розпочинається «роздвоєння» залежності $Q\left(T_{o}\right)$. Так, для кривої 1 такою температурою $є T_{01}{ }^{*} \approx 50^{\circ} \mathrm{C}$. При температурах, нижчих $50^{\circ} \mathrm{C}$, залежності $Q\left(T_{o}\right)$, розраховані для порожнини максимальним радіусом 0,05 мм, співпадають для всіх частот 3 діапазону $(20 \div 100)$ кГц. Це зумовлено тим, що для всіх частот виконуються умови для варіанту розрахунку А), коли пара залишається насиченою протягом всього часу розтягнення порожнини. При температурах, вищих $50^{\circ} \mathrm{C}$, суцільною лінією показана залежність $Q\left(T_{o}\right)$, розрахована для частоти 20 кГц. Як видно, вона $\epsilon$ безпосереднім продовженням низькотемпературної ділянки. Це $\epsilon$ наслідком того, що на частоті 20 кГц пара в зростаючій порожнині досягає насиченості у всьому діапазоні температур. Хід залежності $Q\left(T_{o}\right)$ за таких умов однозначно корелює з залежністю $\rho_{\text {нас }}\left(T_{o}\right)$ густини насиченої пари від рівноважної температури.
Переривчастою лінією проведена ділянка кривої $Q\left(T_{o}\right)$, розрахована для частоти 100 кГц. В цілому відповідну ділянку кривої $Q\left(T_{o}\right)$ при температурах, вищих за $T_{01}{ }^{*} \approx 50^{\circ} \mathrm{C}, 3$ достатньою точністю можна апроксимувати лінійною залежністю. Якщо проаналізувати детальніше, видно, що в діапазоні температур $50-65^{\circ} \mathrm{C}$, коли тільки встановлюється новий характер залежності $Q\left(T_{o}\right)$, відхилення розрахункових точок від апроксимуючої прямої $є$ максимальним, але не перевищує 10-11\%. Причина значної розбіжності розрахункових значень відносно апроксимуючої прямої саме у цьому діапазоні температур полягає у тому, що при визначенні параметрів $\Delta q_{i}\left(r_{i}\right)$ створені умови для реалізації ускладненого варіанту розрахунку В) - пара в порожнині $\epsilon$ насиченою на перших кроках розтягнення порожнини, і залишається суттєво ненасиченою на заключних кроках. Очевидно, зменшення інтегрального параметру $Q$ обумовлено ненасиченістю пари в порожнині, а значна розбіжність значень - це наслідок послідовного використання суттєво різних виразів (7) і (8) для розрахунку кожного інтегрального параметра $Q\left(T_{o}\right)$ у вка- 
заному температурному діапазоні. При подальшому підвищенні температури реалізуємо варіант розрахунку Б), коли пара залишається ненасиченою протягом всього часу зростання порожнини (див. Таблицю 2). Як наслідок, відхилення розрахункових точок від апроксимуючої лінійної залежності значно зменшується. Узагальнюючи зазначимо, що зміна характеру залежності $Q\left(T_{o}\right)$ і формування характерного «зламу» на графіку зумовлені зміною умов для випарування рідини на високих частотах.

Для порожнин більшого радіусу (криві 2,3 рисунку 3) зазначені особливості зберігаються. Для нижньої граничної частоти 20 кГц практично у всьому діапазоні температур пара в процесі росту порожнини залишається насиченою. Отже на частоті 20 кГц криві $Q\left(T_{o}\right)$ для всіх радіусів порожнин однозначновизначаються залежністю $\rho_{\text {нас }}\left(T_{o}\right)$. Для всіх показаних радіусів існує діапазон температур, у якому частота коливань не впливає на хід залежності $Q\left(T_{o}\right)$. Але ширина цього діапазону залежить від радіусу: при зростанні максимального радіуса порожнини параметр $T_{\mathrm{o}}{ }^{*}$ зсувається в область нижчих температур.

Заштриховане поле показане для кривої 1, охоплює множину кривих $Q\left(T_{o}\right)$, що відповідають частотам 3 діапазону $(20 \div 100)$ кГц. Очевидно, що це справедливе і для решти графіків, представлених на рис. 3. Іншими словами, заштрихована та аналогічні області між суцільними та пунктирними залежностями кривих $Q\left(T_{o}\right)$ охоплюють усі розраховані значення параметру $Q$, при всіх допустимих частотах і температурах.

Хід кривих, представлених на рисунку 3 , повертає нас до питання, чи варто підвищувати температуру середовища $T_{o}$ для збільшення потужності теплового потоку на високих частотах $(75 \div 100$ кГц). Очевидно, що підвищення температури не дає бажаного зростання параметру $Q$, оскільки пара в порожнині стає ненасичено, і їі густина $\rho$ може бути в декі-

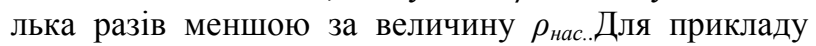
розглянемо хід кривої 3 для порожнини 3 максимальним радіусом 0,1 мм. На частоті 20 кГц зростання температури середовища від $30^{\circ} \mathrm{C}$ до $45^{\circ} \mathrm{C}$ супроводжується зростанням інтегрального параметру $Q$ більше ніж в два рази, на величину $\Delta Q=(0,65-$ $0,30)=0,35$ мкДж, або у відносних одиницях на $117 \%$. У той же час на частоті 100 кГц такому ж зростанню температури відповідає абсолютний приріст $\Delta Q=(0,38-0,30)=0,08$ мкДж, або у відносних одиницях $27 \%$. Аналогічні результати маємо і для кривих 1 i 2 рисунку 3, що відповідають порожнинам меншого радіусу. Отже при температурах, більших температури $T_{o}$, яка відповідає розгалуженню кривих $Q\left(T_{o}\right)$, використання високочастотних ультразвукових коливань стає суттєво неефективним з точки зору формування звукокапілярного потоку тепла через переріз капіляра.
Підводячи підсумок, зазначимо таке.

1. При виборі оптимальних умов формування звукокапілярного потоку теплоти підвищення частоти ультразвукових коливань $є$ недоцільним. Для даної рідини необхідно обирати значення частоти, яке наближається до нижньої границі припустимого технологічного діапазону.

2. Для збільшення потоку тепла через переріз капіляру в ультразвуковому полі доцільно підвищувати температуру, не виходячи за межі режиму розтягнення порожнин, коли пара в порожнині є насиченою. Цей режим подовжується в область більших температур, саме при використанні низькочастотного ультразвуку.

3. Визначені обмеження, які накладає частота ультразвукових коливань на діаметр капіляра та температуру рідини, необхідно враховувати при конструюванні охолоджуючих пристроїв 3 використанням фазових переходів у локально-обмеженій області рідини, збудженої кавітаційним процесом.

\section{ЛІТЕРАТУРА}

1. G. V. Brown, 1976. Magnetic heat pumping near room temperature// J. Appl. Phys., 47(8), 3673.

doi: 10.1063/1.323176

2. Backhaus, S, Swift. G.W 2000. A thermo-acousticStirling heat engine: Detailed study. Journ. Acoust. Soc. Amer., 107 (6), 3148.

doi:10.1121/1.429343

3. О.Ю. Розіна, В.Б.Роганков. Про генерацію теплового потоку на перерізі капіляравнаслідок неоднорідності акустичного поля. ЖХТ,2015. №3, с. 53-61. doi:10.15673/0453-8307.3/2015.42637

4. Ультразвук.- М.: Советская энциклопедия, 1979.$400 \mathrm{c}$.

5. Исакович М.А. Общая акустика. - М.: Наука, 1973. -495 c.

6. Ржевкин С.Н. Курс лекций по теории звука. - М.: Из-во Московского у-та, 1960.-334 с.

7. Розина Е.Ю. Движение жидкости в капилляре при различных режимах ультразвукового воздействия// Акуст. вісник.- 2001.-Т.4, №2.- С.64-72.

doi: 10.1615/InterJFluidMechRes.v33.i5.70

8. Хаппель Дж., Бреннер Г. Гидродинамика при малых числах Рейнольдса.- М.: Наука, 1976.- 630 с.

9. Воинов А.В., Петров А.Г. Движение сферы переменного объема в идеальной жидкости около плоской поверхности// Механика жидкости и газа.- 1971, № 5.- C.91-103.

10. Розин Ю.П., Розина Е.Ю. Влияние газосодержания жидкости на физико-химические процессы, стимулированные кавитацией// Журн. физ. хим. - 1986.T.60, № 6.- c.1495-1500.

Отримана в редакції 28.10.2015, прийнята до друку 18.12.2015 
O. Yu. Rozina, V. B.Rogankov

Odessa national academy of food technologies, 112 Kanatnaya str., Odessa, 65039, Ukraine

\title{
THE OPTIMAL CONDITIONS FOR THE GENERATION OF HEAT FLUX THROW THE CAPILLARY CUT CAUSED BY THE ULTRASONIC CAVITATION
}

\begin{abstract}
The present paper concerns the generation of the sonic-capillary heat flux. Its conceptual model was presented in paper [1] and based on the experimental investigation of the sonic-capillary effect. The main statements of this model are: if the capillary was immersed into liquid, where an ultrasonic field was formed, the cavitations arise near the capillary cannel and due to the sonic-capillary force are translating into the capillary. Thus, all thermodynamic processes, connected with extension of cavities need some quality of heat should be located near the capillary cannel; the decreasing of cavities and reverse of heat to liquid are located in the capillary cannel; that's why the heat flux is form throw the open capillary section. In this paper the results of numerical investigation of the optimal conditions for the generation of the sonic-capillary heat flux are presented. Using the original program product, the influence of the cavity parameters on the heat flux is investigated. It is shown, that an ultrasonic frequency $v$ determines the acceptable range of the internal diameters of the capillary, and, as consequence, the permissible range of cavities radius $R_{\max }$ can be also defined. The calculations cover the range $v=(20 \div 100) \mathrm{kHc}$, and corresponding range of cavities radius $R_{\max }=(0,025 \div 0,100) \mathrm{mm}$. Also, the results of numerical investigation for the wide range of equilibrium temperature of liquid are presented. It is shown, that due to the arising of the equilibrium temperature the kinetics of vaporization changes its parameters: the vapor in cavity remains unsaturated, thus the quality of heat, transferred throw the open end of capillary, decreases. The boundary temperature for two regimes of the evaporating is caused by the ultrasonic frequency too.
\end{abstract}

Keywords: Heatflux-Capillary-Ultrasonic cavitations -Phase transition

\section{REFERENCES}

1. Brown, G.V. 1976. Magnetic heat pumping near room temperature. J. Appl. Phys., 47(8), 3673

doi: $10.1063 / 1.323176$

2. Backhaus, S, Swift. G.W 2000. A thermo-acousticStirling heat engine: Detailed study. Journ. Acoust. Soc. Amer., 107 (6), 3148 doi:10.1121/1.429343

3. Rozina O.Yu, Rogankov V.B. 2015, Refrig.Eng.and Tec. 51(3), 53. doi:10.15673/0453-8307.3/2015.42637

4. Ultrusonic. Sovetckaya enciklopediya, 1979.- 400 p.

5. Rgevkin, S.Y. 1960. Lections on theory of sound. Moscow University Press, 334 p.
6. Isakovich, M. A. 1973. General acoustic. Nauka, $495 \mathrm{p}$.

7. Rozina, E. Yu. 2001. Motion of a Fluid in a Capillary at Various Regimes of the Ultrasound Action. Acoust. Visnik, 4(2), 64

doi/10.1615/interjfluidmechres.v31.i4.80

8. Happel, J., Brenner, H. 1965. Low Reynolds number Hydrodinamics. Prentice-Hall, 630 p.

9. Voinov A. V., Petrov A. G. 1971, Fluid Dynamics (5) 91

10. Rozin, Yu. P, Rozina, E. Yu. 1986. Rus. Journ. of Phys. Chem. A, 60 (6), 1495. 